AperTO - Archivio Istituzionale Open Access dell'Università di Torino

\title{
Hepatitis delta virus diagnosis.
}

\section{This is the author's manuscript}

Original Citation:

\section{Availability:}

This version is available http://hdl.handle.net/2318/130652

since

Published version:

DOI:10.1055/s-0032-1323627

Terms of use:

Open Access

Anyone can freely access the full text of works made available as "Open Access". Works made available under a Creative Commons license can be used according to the terms and conditions of said license. Use of all other works requires consent of the right holder (author or publisher) if not exempted from copyright protection by the applicable law. 


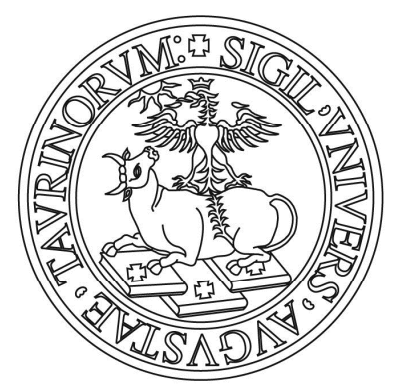

\section{UNIVERSITÀ DEGLI STUDI DI TORINO}

This is an author version of the contribution published on:

Questa è la versione dell'autore dell'opera:

Olivero A, Smedile A. Hepatitis delta virus diagnosis.

Semin Liver Dis. 2012 Aug;32(3):220-7. doi: 10.1055/s-0032-1323627.

Epub 2012 Aug 29. Review. PubMed PMID: 22932970.

The definitive version is available at:

La versione definitiva è disponibile alla URL:

[https://www.thieme-connect.com/ejournals/abstract/10.1055/s-0032-1323627] 


\section{HDV DIAGNOSIS}

Olivero Antonella and Smedile Antonina

Gastroenterology and Hepatology Department, Laboratory of Digestive and Liver Physiopathology, ñSan Giovanni Battistaò Hospital and Department of Internal Medicine, University of Turin, Italy

E-mail:

Olivero Antonella, PhD: antonella.olivero@ unito.it Smedile Antonina, MD: antonina.smedile@unito.it

Corresponding author:

Smedile Antonina, MD: Gastroenterology and Hepatology Department; Laboratory of Digestive and Liver Physiopathology; ñSan Giovanni Battistaò Hospital and Department of Internal Medicine, University of Turin, C.so Bramante, 88 ï 10126 Torino, Italy.

Phone: 00390116333629

Fax: 00390116333976

e-mail: antonina.smedile@unito.it 


\begin{tabular}{|c|c|}
\hline HDV & hepatitis delta virus \\
\hline $\mathrm{HD}-\mathrm{Ag}$ & hepatitis D antigen \\
\hline Anti-HDV & antibody to hepatitis delta virus \\
\hline Anti-HD IgG & IgG antibody to hepatitis delta virus \\
\hline Anti-HD IgM & IgM antibody to hepatitis delta virus \\
\hline HDV-RNA & hepatitis delta virus genome \\
\hline HDV-1,2,3 & hepatitis delta virus genotypes \\
\hline CHD & chronic hepatitis delta \\
\hline $\mathrm{HBV}$ & hepatitis B virus \\
\hline HBsAg & hepatitis B surface antigen \\
\hline Anti-HBc & antibody to hepatitis B core \\
\hline Anti-HBc IgM & IgM antibody to hepatitis B core \\
\hline HBeAg & hepatitis B e antigen \\
\hline Anti-HBe & antibody to hepatitis $\mathrm{B}$ e antigen \\
\hline $\operatorname{cccDNA}$ & covalently closed circular DNA \\
\hline pgRNA & pregenomic RNA \\
\hline $\mathrm{HBV}-\mathrm{D}, \mathrm{A}, \mathrm{B}, \mathrm{C}, \mathrm{F}$ & hepatitis B virus genotypes \\
\hline $\mathrm{HCV}$ & hepatitis $\mathrm{C}$ virus \\
\hline HIV & human immunodeficiency virus \\
\hline AIDS & acquired immune deficiency syndrome \\
\hline PEG-IFN & pegylated interferon \\
\hline LAM & lamivudine \\
\hline ADV & adefovir \\
\hline
\end{tabular}




\section{$\underline{\text { Abstract }}$}

The first step in the diagnosis of Hepatitis Delta Virus Infection is testing HBsAgpositive individuals for the antibody to the HD antigen (anti-HD).

In anti-HD-positive subjects, the next step is testing for HDV-RNA in serum to determine whether the antibody reflects an ongoing active HDV infection (HDV-RNA positive) or represents a serological scar to past HDV infection (HDV-RNA negative). In the HDVpositive individual with liver disease, it is critical to distinguish acute HDV/HBV coinfection from chronic HDV superinfection in HBsAg carriers; the course, prognosis and management of the two conditions are different. The differential diagnosis can be achieved through the scrutiny of the battery of HDV and HBV markers, which combine in patterns characteristic for each condition.

Standardized competitive and $\mu$-capture commercial assays are available to determine the IgG and IgM antibody to HDV. Several in-house assays were developed to determine HDVRNA in serum; the sensitivity threshold of current PCR-based assays is 10 copies of HDV$\mathrm{RNA} / \mathrm{ml}$.

Unfortunately, HDV-RNA assays are not yet standardized and the results from different laboratories often are not comparable due to different sensitivities. The development of an International reference HDV-RNA standard remains an unmet diagnostic need. 


\section{$\underline{\text { Introduction }}$}

Indicative of HDV infection are the replication of the viral RNA with the expression of the HD-Antigen (HD-Ag) and the specific immune reaction of the infected host (1). In the immunocompetent host, HDV infection elicits an antibody response to the HD-Ag (anti$\mathrm{HD}$ ), first of IgM then of IgG class (2). Active HDV infection is diagnosed on the finding of the HDV-RNA in serum and/or the HD-Ag in serum and liver.

As hepatitis D results from a double infection with the HBV, the virologic assessment requires the consideration not only of HDV but also of the concomitant HBV infection. In the clinical setting efforts to diagnose HDV infection are appropriate only in the presence of the HBsAg in serum; HBsAg-negative patients do not harbour productive HDV infections.

This review summarizes the virologic profiles diagnostic of HDV infections and provides an analysis of each marker, relevant to the diagnosis of hepatitis D.

\section{Serologic patterns of HDV infection}

The HDV is acquired either through simultaneous coinfection with the HBV by HBV naïve individuals or through superinfection on a pre-existing and persisting HBV state i.e. on individuals carrying the HBsAg (3). The clinical outcome is different, coinfection usually runs, a self-limited course that terminates with the clearance of $\mathrm{HBV} / \mathrm{HDV}$, superinfection usually induces a chronic hepatitis D that advances to cirrhosis and liver failure.

The distinction of coinfection from superinfection is critical to the management and prognosis; it is made possible by the scrutiny for HDV and HBV markers, which discloses serologic patterns typical for the two conditions (fig. 1).

In coinfection (fig. 1A) the expression of HDV is determined by the virulence of the concomitant HBV infection (4). With diminished HBV virulence, HDV expression is shortlived, viremia transient and the anti-HD response brief or abortive. Coinfections with large HDV expression exhibit a full serological pattern, consisting of early viremia and HD antigenemia, followed by seroconversion first to $\operatorname{IgM}$ and then to $\operatorname{IgG}$ anti-HD; HD-Ag is 
expressed in liver and the HD-RNA peaks to high titers in serum. The antibody response may be delayed for several days; therefore prolonged monitoring for antibodies to HDV is required to exclude or confirm HDV infection in patients with an acute HBsAg-positive hepatitis. The IgM antibody to the core antigen of the HBV (IgM anti-HBc) as well as HBVDNA are present in high titers; the $\mathrm{HBeAg}$ may also be detectable at onset of disease, but rapidly clears from serum followed by seroconversion to anti-HBe.

Atypical patterns of acute coinfection were reported in hepatitis D occurring among drug addicts (5). In some patients, strong and early repression of HBsAg resulted in an HBsAg-seronegative hepatitis with positive HDV serology, followed by the return of the HBsAg after the clearance of HDV (6); in a few patients, superinfection terminated the HBsAg state with seroconversion to anti-HBs (7). In a recent single case report, acute hepatitis D has terminated also chronic HCV infection (8). In other patients coinfection run a byphasis course, with two hepatitis bouts accompanied by sequential expression of either the HBV or HDV (9-10).

In superinfection, the virological pattern is more uniform. HDV-viremia appears early and the $\operatorname{IgM}$ and $\operatorname{IgG}$ anti-HD response is brisk (11). Both antibodies rapidly increase in superinfection progressing to cronicity and remain detectable in high titers along with the persistence of viremia and the progression to chronic hepatitis D (CHD); in the liver, the nuclei of hepatocytes are loaded with HD-Ag.

In most of the patients replication of HBV is repressed; serum HBV-DNA is null or present at low titers. The IgM anti-HBc is usually negative (Fig. 1B) (12). The patterns diagnostic of the various clinical forms of HDV infection are summarized in table 1.

The role of quantitative HBsAg testing in CHD remains under investigation. A correlation was observed between the decrease in serum of HBsAg and the decline of serum HDV-RNA in patients treated with Peg-IFN or with lamivudine; levels of HBsAg decreased also in patients treated with Peg-IFN in combination with Adefovir but not in patients treated with Adefovir monotherapy (13). The decrease of serum HBsAg might provide a valuable marker prognostic of the decline and ultimate clearance of HDV infection (14). 


\section{Antibodies to HDV}

a) IgG anti-HD

Total antibodies to HDV are detected with a Enzyme Linked Immunosorbent Assays (ELISA). Commercial tests are available (ETI-AB-DetlaK-2 Sorin, Saluggia, Italy; Abbott IgM anti-HD). The method is a simultaneous competitive assay. The format includes a solidphase (plastic wells) coated with recombinant HDAg, test sample, anti-HD negative control, an enzyme tracer (anti-HD-Fab human-conjugated with horseradish peroxidase) and a chromogen substrate to develop the colour of the enzyme tracer that binds to the solid phase. Anti-HD in the sample and labelled anti-HD compete for the fixed quantity of HDAg bound to the solid phase; the amount of enzyme activity bound to the solid phase is inversely proportional to the concentration of anti-HD in the sample.

Competitive assays measure all types of antibodies to HDV; however, antibodies other than IgG are a minority of the total reactivity and in practice the measure of total antibodies by competitive assays is synonymous with the measure of $\operatorname{IgG}$ antibodies $(2,12)$. The $\operatorname{IgG}$ antibody is not protective; it is present in all immunocompetent patients with HDV infection, coexisting with active HDV infection and hepatitis $\mathrm{D}$, and may not be raised in immunocompromised patients who acquire HDV such as patients with AIDS (15). The IgG antibody is usually short-lived in coinfected patients who clear HBV-HDV. Exception are the drug addicts; in a retrospective analysis of blood from 27 Swedish drug addicts drawn 513 years after the acute episode of HDV coinfection, 26 were clear-cut positive and one still gave a borderline positive result for anti-HD (16).

Anti-HD may persist for years as a serological scar in superinfected patients who clear HDV infection and remain HBsAg-positive; rarely it was also detected in HBsAg-negative subjects, who were superinfected in the past and cleared HBV with the loss of the HBsAg (17).

b) IgM anti-HD

The IgM antibody to HDAg (IgM anti-HD) is measured with $\mu$-capture immunoassays; titration is made by tenfold dilutions (18). Assays are available 
commercially( ETI-Delta-IgM-K2 assay, Sorin, Saluggia, Italy; anti-HD EIA Abbott, AntiHD IgM Kit, Serono, Italy). In chronic infection the antibody is composed mainly of monomeric 7S IgM molecules while $19 \mathrm{~S}$ pentameric molecules are prevalent in primary HDV infection (19).

The IgM anti-HD is considered a marker of HDV-induced liver disease and may be a useful surrogate to determine HDV replication if molecular tests for HDV RNA are not available. The decrease and clearance of this antibody in chronic hepatitis D is a predictor of spontaneous or therapy ï induced disease remission (2,20,21). In 38 Italian HDV patients treated with Peg-Interferon and Ribavirin, all positive for IgM anti-HD at baseline with a mean titer of $10^{4}$, the antibody titer remained unchanged in virologic non-responders and in those in whom HDV-RNA decreased but did not clear from serum; in 5 patients who cleared HDV-RNA the mean antibody titer diminished by $1 \log ^{10}$ and it disappeared in 2 patients who achieved a sustained response 6 months off from therapy (22).

\section{The HD-Antigen}

The HD Antigen is expressed in the liver cell nuclei where it can be detected by immunochemistry $(2,4)$. With the advent of molecular assays for HDV-RNA in serum, tissue immunochemistry has become obsolete (23); it requires an invasive liver biopsy and is less sensitive than molecular assays. The percentage of cells expressing HDAg diminishes with the progression of chronic hepatitis $\mathrm{D}$ to cirrhosis making immunohistologic testing inaccurate in patients with advanced disease. It can be used for the diagnosis of active HDV infection if molecular tests for HDV-RNA are not available.

After disruption of the HDV virion with detergent, the HD-Antigen is exposed and can be measured in serum with assays based on its capture by anti-HD fixed in a solid phase and subsequent binding to it of anti-HD conjugated with an enzyme tracer $(2,12)$. Commercial assays are available (ETI-Delta-2, Sorin, Saluggia, Italy; HDAg Sanofi, Pasteur). However, immunocompetent patients exposed to HDV invariably develop in a short-while anti-HD, which binds and masks the serum antigen released from the virion, rendering it unavailable to the format. Serum HD antigen is detectable only transiently in blood specimens collected early at the onset of hepatitis $\mathrm{D}$, before the rising of antibodies, and its finding is therefore diagnostic of primary HDV infection. Occasionally the HDAg can be detected for long in 
serum of patients with an impaired immune system who do not raise antibodies, such as patients with AIDS or transplanted patients under pharmacological immunosuppression $(15,24)$.

\section{HDV RNA}

Serum HDV-RNA was first determined with nucleic acid hybridization assays that used the cloned HDV genome or cDNA constructs of it (25). With the advent of Reverse Transcription (RT) - PCR techniques, HDV RNA has been measured with qualitative or semiquantitative RT-PCR assays. Sensitivity has markedly improved, with current detection limits of 1000 genome/ml for simple PCR and of 10 genome/ml for nested PCR (26) (fig. 2). A first method for the quantitation of HDV-RNA, based on the application of Real-Time PCR technique, has been described by Yamashiro in 2004 (27). In this assay, primers are designed on the template of the HD-Ag coding region; this is a highly conserved region with a homology of $98 \%$ between genotype 1 and genotype 2 . In the assay of Le Gal (28) the design of primers and probe is targeted to a conserved region, located within the ribozyme. The assay allows the detection of all HDV genotype; a further forward primer specific for HDV 3 genotype was used to determine HDV-3 infection. With the procedure described by Hoffmann (29), genotype 1 can be distinguished from genotype 3 by the analysis of the results from a melting curve performed after the polymerase chain reaction. Mederacke has established an in-house real-time PCR assay, exploiting the utility channel of the Cobas TaqMan apparatus (Roche Diagnostics) (30); the use of a real-time PCR platform, in association with a system for the automatic extraction of RNA, provides more reproducible results. In the assay developed by Pollicino (31), HDV-RNA has also been quantified by real -time PCR with the utility channel of Cobas TaqMan instruments; with this assay, HDV RNA can be quantified in serum and in liver. Table 2 and 3 report the principal technical features of in-house Real Time PCR methods and of commercial assays published in the last decade.

Unfortunately the results from different laboratories are often not comparable due to the diverse sensitivity of the assays; variance is caused by the use of different set of primers 
and by the variability of the RNA region amplified.

To reduce false negative results and optimize specificity for all HDV genotypes, primers and probes should be targeted to the most highly conserved regions, located within the ribozyme. The standards utilized in different assays are heterogeneous; they include synthetic HDVRNA, HDV cDNA plasmid, serum from HDV infected patients or Armored RNA (complex of MS2 bacteriophage coat protein and RNA). With a cDNA standard it is not possible to check the reverse transcription step while simple optical density measurements are not sufficient to quantify synthetic RNA standards, whose performance is variable for the presence of secondary structures different from natural HDV-RNA. To calibrate quantitative assays, it would be desirable that WHO develops an HDV-RNA reference preparation quantified in International Unit and makes it available as an international standard.

HDV-RNA quantification does not seem to correlate with the clinical stage of liver disease (3). It is useful to monitor treatment response in patients undergoing antiviral therapy and may be useful in longitudinal studies to assess the dynamics of HDV replication over time in infections with other hepatitis viruses.

\section{HDV Genotypes}

Eight major clades of HDV-RNA have been identified, differing each other for about $40 \%$ of the nucleotide sequence (32). Genotypes may be determined by Restriction Fragment Length Polymorphism (RFLP) analysis or by direct sequencing (33). Genotyping is currently performed only in research laboratories. It has been valuable in tracing source and spreading of HDV infection (34); in areas where both genotypes 1 and 2 are present, it may help to identify patients infected with genotype 1 , which has a worse outcome than genotype 2 . In an Italian cohort (31), $21 \mathrm{HDV}$ patients were infected with HDV-1 and HBV genotype D; among $22 \mathrm{HBV}$-monoinfected controls, genotype HBV-D was found in 18, genotype HBV$\mathrm{A}$ in 4, genotype HBV-C in 1. The genotype of HBV seems to have no clinical relevance in the context of HDV infection, with the exception of the combination of HBV genotype F and HDV genotype 3 in South America, which was correlated with severe forms of hepatitis D

(35). In the Western world the prevalent HDV-1 genotype combines with genotype D, A and $\mathrm{C}$ without clinical differences; new HBV genotypes incoming with immigration, such as 
genotype B from China and genotype E from sub-Saharian Africa are unlikely to have an impact in the clinical expression of HDV infection.

\section{IgM antibody to the Hepatitis B core antigen (IgM anti-HBc)}

The IgM anti-HBc is a surrogate marker of liver disease induced by HBV replication and its determination is useful to distinguish whether an acute HDV-positive hepatitis is caused by HBV-HDV coinfection (IgM anti-HBc positive) or by HDV superinfection in an inactive HBsAg carrier (IgM anti-HBc negative) and whether the concomitant chronic HBV infection is also pathogenic in CHD (IgM anti-HBc positive) $(2,4)$.

\section{Interactions of HDV with HBV, HCV and HIV}

Due to the dominance of HDV over HBV, the majority of patients with CHD have in serum anti-HBe and null or low HBV-DNA. Exceptions are drug-addicts and immigrants; a fair proportion have fresh $\mathrm{CHD}$ accompanied by active $\mathrm{HBV}$ infection with serum $\mathrm{HBe} \mathrm{Ag}$ and consistent levels of HB viremia (3).

Triple infections with HBV/HDV/HCV are common in drug addicts. In Germany, $29 \%$ of a total of $254 \mathrm{HDV}$ patients were also positive for anti-HCV (36). Most of the German-born patients were drug-addicts and $54 \%$ had antibody to HCV; only $8 \%$ of the HDV patients born in Turkey and 24\% of those born in Eastern Europe had anti-HCV.

In multiple viral infections (HDV/HBV/HCV/HIV), HDV is usually dominant and inhibits the others viruses. In the study of the European cohort of HIV (EuroSIDA) (37), anti-HD was detected in $62(14.5 \%)$ of $422 \mathrm{HBV} / \mathrm{HIV}$; serum HDV-RNA was detectable in $87 \%$ the antibody positive patients with a median titer of $1.76 \times 10^{7}$ copies $/ \mathrm{ml}$. Infection with HDV was associated with a severe chronic hepatitis/cirrhosis and a consistent mortality risk.

In multiple infections viral dominance may change and alternate over time, with serum HBV-DNA and HCV-RNA reaching occasionally high levels. In a bimonthly surveillance of the levels of $\mathrm{HDV} / \mathrm{HBV} / \mathrm{HCV}$ during 12 months in 15 Italian patients with triple infection (38), 8 exhibited alternating peaks of $\mathrm{HBV}$ and/or/HCV replication. Similar fluctuations were observed in HDV cohorts form Germany and Spain and $(3,39)$, suggesting that serum levels of HDV, HBV and HCV should be measured longitudinally in order to tailor antiviral 
therapy.

\section{Liver HDV-RNA}

HDV-RNA can be detected in liver with qualitative Northern hybridization assays (25). The advent of qPCR technology has provided quantitative assays for the measure of nucleic acids in small biopsy samples, overcoming the limitation of sufficient material for the extraction; however, the need for an invasive liver biopsy restricts the clinical use of this procedure. The molecular interplays of HDV and HBV were investigated in serum and liver with sensitive qPCRs in 21 coinfected HDV/HBV patients and in $22 \mathrm{HBV}$-monoinfected patients (31). In HDV patients the median level of serum HBV-DNA was $5 \log ^{10}$, and of intrahepatic relaxed-circular DNA and cccDNA was $2 \log ^{10}$, significantly lower than in HBV-monoinfected. Although pgRNA and pre-S/S RNA in liver were also diminished (by 1 $\log ^{10}$ ) in HDV-patients, the serum HBsAg concentration was comparable between the two groups; large deletions in the basal core promoter/precore region were detected in $5 \mathrm{HDV}$ patients, all of whom had low levels of serum HBV.

These findings provide a molecular basis to the discrepancy between the biological help that HDV requires from HBV and the repression that it regularly exerts on the helper virus; the HDV is smart enough to selectively suppress some HBV functions while maintaining the capacity of $\mathrm{HBV}$ to synthesize the large amounts of envelope proteins necessary to the formation of HDV virions and to virus survival. 


\section{References}

1. Rizzetto M. Hepatitis D: thirty years after. J Hepatol. 2009; 50:1043-50.

2. Smedile A, Rizzetto M, Gerin JL. Advances in hepatitis D virus biology and disease. In: Progress in liver disease. Eds: JL Boyer, RK Ockner. WB Saunders Company. Vol XII, 157-175; 1994.

3. Wedemeyer H, Manns MP. Epidemiology, pathogenesis and management of hepatitis D: update and challenges ahead. Nat Rev Gastroenterol Hepatol. 2010; 7:31-40.

4. Farci P. Delta hepatitis: an update. J Hepatol. 2003; 39 Suppl 1:S212-9. Review.

5. Caredda F, Antinori S, Re T, Pastecchia C, Moroni M. Course and prognosis of acute HDV hepatitis. Prog Clin Biol Res. 1987; 234:267-76.

6. Caredda F, Antinori S, Pastecchia C, et al. Presence and incidence of hepatitis delta virus infection in acute HBsAg-negative hepatitis. J Infect Dis 1989; 159:977-979.

7. Moestrup T, Hansson BG, Widell A, Nordenfelt E. Clinical aspects of delta infection. Br Med J. 1983; 286:87-90.

8. Deterding K, Pothakamuri SV, Schlaphoff V, Hadem J, Metzler F, Bahr MJ, Manns MP, Cornberg M, Wedemeyer H. Clearance of chronic HCV infection during acute delta hepatitis. Infection. 2009; 37:15962.

9. De Cock KM, Govindarajan S, Valinluck B, Redeker AG. Hepatitis B virus DNA in fulminant hepatitis B. Ann Intern Med. 1986; 105:546-7.

10. Govindarajan S, Valinluck B, Peters L. Relapse of acute B viral hepatitis-role of delta agent. Gut.1986; 27:19-22.

11. Rizzetto M, Ponzetto A, Bonino F, Smedile A. Hepatitis delta virus infection: clinical and epidemiological aspects. In Zuckerman AJ, ed. Viral hepatitis and liver disease. New York: Alan R. Liss, 1988: 389-94.

12. Negro F, Rizzetto M. Diagnosis of hepatitis delta virus infection. J Hepatol. 1995; 22(1 Suppl):136-9.

13. Wedemeyer H, Yurdaydìn C, Dalekos GN, Erhardt A, Çakaloĵ lu Y, Dể ertekin H, Gürel S, Zeuzem S, Zachou K, Bozkaya H, Koch A, Bock T, Dienes HP, Manns MP; HIDIT Study Group. Peginterferon plus adefovir versus either drug alone for hepatitis delta. N Engl J Med. 2011; 364:322-31.

14. Olivero A, Fontana R, Niro GA, et al. Kinetics of HDV-RNA and Hepatitis B Surface Antigen in chronic delta hepatitis under pegylated interferon and/or nucleoside analogs therapy. Hepatology 2011; 54: 1077A.

15. Roingeard P, Dubois F, Marcellin P, Bernuau J, Bonduelle S, Benhamou JP, Goudeau A. Persistent delta antigenaemia in chronic delta hepatitis and its relation with human immunodeficiency virus infection. $\mathrm{J}$ Med Virol. 1992; 38:191-4.

16. Moestrup T, Hansson BG, Widell A, Nordenfelt E, Hägerstrand I. Long term follow up of chronic 
hepatitis B virus infection in intravenous drug abusers and homosexual men. Br Med J. 1986; 292:854-7.

17. Niro GA, Gravinese E, Martini E, Garrubba M, Facciorusso D, Conoscitore P, Di Giorgio G, Rizzetto M, Andriulli A. Clearance of hepatitis B surface antigen in chronic carriers of hepatitis delta antibodies. Liver. 2001; 21:254-9.

18. Smedile A, Lavarini C, Crivelli $\mathrm{O}$ et al. Radioimmunoassay detection of $\operatorname{IgM}$ antibodies to the HBVassociated delta (d) antigen; clinical significance in d infection. J. Med. Virol 1982; 9:131-138.

19. Borghesio E, Rosina F, Smedile A, Lagget M, Niro MG, Marinucci G, Rizzetto M. Serum immunoglobulin $\mathrm{M}$ antibody to hepatitis $\mathrm{D}$ as a surrogate marker of hepatitis $\mathrm{D}$ in interferon-treated patients and in patients who underwent liver transplantation. Hepatology. 1998; 27:873-6.

20. Poggio PD, Colombo S, Zaccanelli M, Rosti A. Immunoglobulin M anti-hepatitis D virus in monitoring chronic hepatitis delta. Liver Int. 2011; 31:1598. doi: 10.1111/j.1478-3231.2011.02518.x.

21. Mederacke I, Yurdaydin C, Dalekos GN, Bremer B, Erhardt A, Cakaloglu Y, Yalcin K, Gurel S, Zeuzem S, Zachou K, Bozkaya H, Dienes HP, Manns MP, Wedemeyer H; Hep-Net/International Delta Hepatitis Study Group. Anti-HDV immunoglobulin M testing in hepatitis delta revisited: correlations with disease activity and response to pegylated interferon-ǓZa treatment. Antivir Ther. 2012; 17:305-12. doi: 10.3851/IMP1926.

22. Niro GA, Ciancio A, Gaeta GB, Smedile A, Marrone A, Olivero A, Stanzione M, David E, Brancaccio G, Fontana R, Perri F, Andriulli A, Rizzetto M. Pegylated interferon alpha-2b as monotherapy or in combination with ribavirin in chronic hepatitis delta. Hepatology. 2006; 44:713-20.

23. Pascarella S, Negro F. Hepatitis D virus: an update. Liver Int. 2011; 31:7-21. doi: 10.1111/j.14783231.2010.02320.x. Epub 2010 Sep 29.

24. Novick DM, Farci P, Croxson TS, Taylor MB, Schneebaum CW, Lai ME, Bach N, Senie RT, Gelb AM, Kreek MJ. Hepatitis D virus and human immunodeficiency virus antibodies in parenteral drug abusers who are hepatitis B surface antigen positive. J Infect Dis. 1988; 158:795-803.

25. Smedile A, Rizzetto M, Denniston K. et al. Type D hepatitis: the clinical significance of hepatitis D virus RNA in serum as detected by a hybridization based-assay. Hepatology 1986; 6:1297-130.

26. Smedile A, Niro MG, Rizzetto M. Detection of serum HDV-RNA by RT-PCR. In: Hamatake RK, Lau JYN, eds. Methods in Molecular Medicine. Totowa, NJ: Humana Press Inc; 2004: 85-93.

27. Yamashiro T, Nagayama K, Enomoto N, et al. Quantitation of the level of Hepatitis Delta Virus RNA in serum, by Real-Time Polymerase Chain Reaction-and its possible correlation with the clinical stage of liver disease. J Infect Dis 2004; 189: 1151-1157.

28. Le Gal F, Gordien E, Affolabi D. et al. Qunatification of hepatitis delta virus RN in serum by consensus real-time PCR indicates different pattern of virological response to interferon therapy in chronically infected patients. J Clin Microbiology. $2005 ; 43$ : 2363-2369.

29. Hofmann J, Frenzel K, Minh BQ, et al. Quantitative detection an typing of hepatitis D virus in human serum by real-time polymerase chain reaction and melting curve analysis. Diagn Microbiol and Infect Dis $2010 ; 67: 172-179$.

30. Mederake I, Brenner B, Heidrich B. et al. Establishement of a novel quantitative HDV RNA assay using the COBAS TaqMan platform to study HDV RNA kinetics. J Clin Microbiol 2010; 2022-2029. 
31. Pollicino T, Raffa G, Santantonio T. et al. Replicative and transcriptional activities of Hepatitis B virus in patients coinfected with Hepatitis B and Hepatitis delta viruses. J Virol 2011 ; $85: 432-439$.

32. Deny P. Hepatitis delta virus genetic variability: from genotype I, II, III to eight major clades? Curr Top Microbiol Immunol 2006; 307: 151-171.

33. Casey J, Niro G, Smedile A, Andriulli A. et al.The predominance of hepatitis delta virus genotype 1 among chronically infected Italian patients. Hepatology 1997; 25: 728-734.

34. Radjef N, Gordien V, Ivaniushina E, et al. Molecular phylogenetic analysis indicate a wide and ancient radiation of African hepatitis delta virus, suggesting a Deltavirus genus of at least seven major clades. J Virol 2004; 78: 2537-2544.

35. Casey JL, Niro GA, Engle R, Vega A, Gomez H, McCarthy M, Watts DM et al. Hepatitis B virus/hepatitis D virus co-infection in outbreaks of acute hepatitis in the Peruvian Amazon basin: the role of HDV genotype III and HBV genotype F. J Infect Dis 1996;174:920-926.

36. Heidrich B, Deterding K, Tillman HL, et al. Virological and clinical characteristics of delta hepatitis in central Europe. J Viral Hepat.2009; 16:883-894.

37. Soriano V, Grint D, dôArminio Monforte A et al. Hepatitis delta in HIV-infected individuals in Europe. AIDS 2011; 25: 1987-1992.

38. Raimondo G, Brunetto MR, Pontisso P, et al. Longitudinal evaluation reveals a complex spectrum of virological profile in hepatitis B virus /hepatitis C virus-coinfected patients. Hepatology 2006; 43: 100107.

39. Schaper M, Rodriguez-Frias F. Jardi R, et al. Quantitative longitudinal evaluations of hepatitis delta virus RNA and hepatitis B virus DNA shows a dynamic, complex replicative profile in chronic hepatitis B and D. J Hepatol 2010; 52: 658-664. 


\section{Legends}

Fig. 1A

Serological pattern of HDV/HBV coinfection: in severe HDV infection appear an early viremia and HD antigenemia followed by a seroconversion first to $\operatorname{IgM}$ and then to $\operatorname{IgG}$ antibodies to HDV. Simultaneously there is the expression of HBsAg and a primary response to $\mathrm{HBV}$ highlighted by the presence of IgM anti-HBcAg.

Fig. 1B

Serological pattern of HDV superinfection evolving to chronicity: HDV-RNA in serum appears early followed by a sudden IgM and IgG antibodies appearance. In most cases $\mathrm{HBV}$ replication is low or repressed and IgM antibodies to $\mathrm{HBc}$ antigen are negative.

Fig. 2

Increase of HDV-RNA sensitivity with the different tests developed over the last 30 years

Table 1. HDV and HBV markers in different clinical forms of HDV infection

Table 2. List of in-house real-time PCRs for HDV-RNA detection

Table 3. List of commercial assays for HDV-RNA detection 
Table I: Serum patterns diagnostic of the different clinical forms of HDV infection

\begin{tabular}{|c|c|c|c|c|c|c|c|c|}
\hline \multirow[b]{2}{*}{ Serum } & \multicolumn{3}{|c|}{ HDV Markers } & \multicolumn{5}{|c|}{ HBV Markers } \\
\hline & $\begin{array}{l}\text { anti-HDV } \\
\text { IgM }\end{array}$ & $\begin{array}{c}\text { anti-HDV } \\
\text { IgG }\end{array}$ & HDV-RNA & HBsAg & HBeAg & anti-HBe & anti-HBc IgM & HBV-DNA \\
\hline \multirow{2}{*}{$\begin{array}{l}\text { Acute Hepatitis } \\
\text { Ǐ Coinfection } \\
\text { Ǐ Superinfection }\end{array}$} & + & + & + & + & + & - & + & $\begin{array}{c}+(>20.000 \\
\mathrm{IU} / \mathrm{ml})\end{array}$ \\
\hline & + & + & + & + & - & + & $-1+-$ & $\begin{array}{c}-/+- \\
(<2.000 \\
\text { IU/ml })\end{array}$ \\
\hline $\begin{array}{l}\text { Chronic } \\
\text { Hepatitis }\end{array}$ & + & + & $\begin{array}{c}+\left(10^{5} \ddot{i} 10^{7}\right. \\
\text { copies/ml })\end{array}$ & + & - & + & - & $\begin{array}{c}-/+- \\
(<2.000 \\
\text { IU/ml })\end{array}$ \\
\hline $\begin{array}{c}\text { Chronic active } \\
\text { HDV/HBV } \\
\text { Hepatitis }\end{array}$ & + & + & $\begin{array}{c}+\left(10^{5} \ddot{\mathrm{I}} 10^{7}\right. \\
\text { copies/ml })\end{array}$ & + & - & + & - & $\begin{array}{c}+(>2.000 \\
\mathrm{IU} / \mathrm{ml})\end{array}$ \\
\hline Cirrhosis & $+/-$ & + & $\begin{array}{c}+/-\left(10^{3} \ddot{\mathrm{i}} 10^{7}\right. \\
\text { copies } / \mathrm{ml})\end{array}$ & + & - & + & - & $\begin{array}{c}-/+- \\
(<2.000 \\
\mathrm{IU} / \mathrm{ml})\end{array}$ \\
\hline HDV recovery & - & + & - & + & - & + & - & $\begin{array}{c}-/+- \\
(<2.000 \\
\mathrm{IU} / \mathrm{ml}) \\
\end{array}$ \\
\hline Liver & HDA & & HDV-RNA & & & HBcAg & HB & -DNA \\
\hline $\begin{array}{l}\text { Chronic } \\
\text { Hepatitis }\end{array}$ & + & & + & & & $-1+$ & & l+ \\
\hline
\end{tabular}


Table II: principal technical features of published in-house Real Time PCR methods for HDV-RNA quantification

\begin{tabular}{|c|c|c|c|c|c|c|c|c|}
\hline METHODS & $\begin{array}{c}\text { HDV-RNA } \\
\text { EXTRACTION }\end{array}$ & $\begin{array}{c}\text { REVERSE } \\
\text { TRANSCRIPTION }\end{array}$ & TARGET REGION & $\begin{array}{l}\text { GENOTYPES } \\
\text { DETECTED }\end{array}$ & $\begin{array}{c}\text { REAL-TIME } \\
\text { PCR } \\
\text { INSTRUMENT } \\
\end{array}$ & STANDARD & LINEARITY & $\begin{array}{c}\text { LIMIT OF } \\
\text { DETECTION }\end{array}$ \\
\hline $\begin{array}{c}\text { Yamashiro et al., J } \\
\text { Infect Dis. 2004; 189: } \\
\text { 1151-7 }\end{array}$ & $\begin{array}{l}\text { Acid guanidium phenol- } \\
\text { chloroform method }\end{array}$ & $\begin{array}{c}\text { Random hexamers (Takara Bio) } \\
\text { RNase inhibitor (Promega) } \\
\text { MMLV Reverse Trancriptase } \\
\text { (Gibco) }\end{array}$ & $\begin{array}{c}\text { HDAg-coding region } \\
\text { Primer 1164 } \\
\text { nt 1164-1192 } \\
\text { Primer } 1297 \\
\text { nt } 1297-1268 \\
\end{array}$ & $1,2 \mathrm{a}, 2 \mathrm{~b}$ & $\begin{array}{l}\text { Light Cycler System } \\
\text { (Boehringer } \\
\text { Mannheim) }\end{array}$ & $\begin{array}{l}\text { Synthetic HDV-RNA } \\
\text { standard }\end{array}$ & $\begin{array}{l}10^{3} \mathrm{i} \quad 10^{9} \text { copies } \\
\mathrm{RNA} / \mathrm{ml}\end{array}$ & $10^{3}$ copies RNA $/ \mathrm{ml}$ \\
\hline $\begin{array}{c}\text { Le Gal et al., } \\
\text { J Clin Microbiol 2005; } \\
\text { 43: 2363-9 }\end{array}$ & $\begin{array}{l}\text { QIAamp MinElute virus } \\
\text { vacuum (Qiagen) }\end{array}$ & $\begin{array}{c}\text { Random Primers } \\
\text { RNase inhibitor (Promega) } \\
\text { SuperScript Reverse } \\
\text { Transcriptase II (Life } \\
\text { Technologies) }\end{array}$ & $\begin{array}{c}\text { Ribozyme region } \\
\text { Delta-F/ T3-Delta-F } \\
\text { nt 693-709 } \\
\text { Delta-R } \\
\text { nt } 891-907 \\
\text { Delta-P } \\
\text { nt } 858-872\end{array}$ & $1-7$ & $\begin{array}{l}\text { ABI PRISM } 7000 \\
\text { (Applied } \\
\text { Biosystems) }\end{array}$ & Plasmid pCRII-dFr45-Râ & $10^{3} \mathrm{i} 10^{9}$ copies $/ \mathrm{ml}$ & $10^{2}$ copies $/ \mathrm{ml}$ \\
\hline $\begin{array}{l}\text { Erhardt et al., Liver } \\
\text { Int 2006; 26: 805-10 }\end{array}$ & $\begin{array}{l}\text { MagNA Pure Compact } \\
\text { Nucleic Acid Isolation } \\
\text { Kit I (Roche } \\
\text { Diagnostics) } \\
\end{array}$ & One Step & HDAg-coding region & $1-3$ & Light Cycler System & $\begin{array}{l}\text { Patient serum calibrated } \\
\text { on HDV plasmid pSVL } \\
\text { LD3 }\end{array}$ & $n r$ & $1,5 \times 10^{2}$ copies $/ \mathrm{ml}$ \\
\hline $\begin{array}{l}\text { Sheldon et al., } \\
\text { Antiviral Therapy } \\
\text { 2008; 13: 97-102 }\end{array}$ & $\begin{array}{l}\text { QiaAMP viral RNA } \\
\text { extraction kit (Qiagen) }\end{array}$ & $\begin{array}{l}\text { AMV Reverse Transcriptase } \\
\text { (Promega) }\end{array}$ & $n r$ & $n r$ & $\begin{array}{l}\text { Light Cycler PCR } \\
\text { thermocycler } \\
\text { (Roche) }\end{array}$ & $\begin{array}{l}\text { DeltaF-R2 PCR DNA } \\
\text { fragment cloned into a } \\
\text { pGEMT vector }\end{array}$ & $10^{-1} \ddot{i} 10^{8}$ copies $/ \mathrm{ml}$ & $10^{2}$ copies $/ \mathrm{ml}$ \\
\hline $\begin{array}{c}\text { Zachou et al., Liver Int } \\
2009 ; 430-7 \\
\end{array}$ & $n r$ & $n r$ & $n r$ & 1 & $n r$ & HDV-cDNA plasmid & $1,1 \times 10^{2}-1,1 \times 10^{5}$ copies & $1,2 \times 10^{2}$ copies $/ \mathrm{ml}$ \\
\hline $\begin{array}{c}\text { Schaper et al., J } \\
\text { Hepatol 2010; 52: 658- } \\
64\end{array}$ & $n r$ & One step & $\begin{array}{l}\text { HDAg-coding region } \\
\text { Primer DP1: nt } 887 \\
\text { Primer DP2: nt } 993 \\
\text { Probe HDV-FL: nt } 921 \\
\text { Probe HDV-LC: nt } 947\end{array}$ & 1 & $\begin{array}{l}\text { LightCycler system } \\
\text { (Roche) }\end{array}$ & $\begin{array}{l}\text { Quantified serum from a } \\
\text { chronic hepatitis Delta } \\
\text { patient }\end{array}$ & $\begin{array}{l}10^{3} \text { ï } 10^{7} \mathrm{HDV}-\mathrm{RNA} \\
\text { equivalent/ml }\end{array}$ & $10^{3}$ equivalent $/ \mathrm{ml}$ \\
\hline $\begin{array}{l}\text { Hofmann et al., Diagn } \\
\text { Microbiol and Infec } \\
\text { Dis 2010; 67: 172-9 }\end{array}$ & $\begin{array}{l}\text { QiaAMP Viral RNA } \\
\text { mini Kit (Qiagen) }\end{array}$ & $\begin{array}{c}\text { Primer Random (Roche) } \\
\text { SuperScript III RT (Invitrogen) }\end{array}$ & $\begin{array}{l}\text { HDAg-coding region } \\
\text { Primer HD10: } \\
\text { nt 469-485 } \\
\text { Primer HD11: } \\
\text { nt 839-819 } \\
\text { Probe HD LNA: } \\
\text { nt } 703-720 \\
\text { Probe HD 13R: } \\
\text { nt 722-740 } \\
\end{array}$ & $\begin{array}{c}\text { Opportunity to } \\
\text { identify HDV-3 by } \\
\text { subsequent melting } \\
\text { analysis }\end{array}$ & $\begin{array}{l}\text { LightCycler } 2.0 \\
\text { instrument (Roche) }\end{array}$ & Plasmid pSC-A HDV-1 & $2 \times 10^{3} \mathrm{i} \quad 10^{8}$ copies $/ \mathrm{ml}$ & $2 \times 10^{3}$ copies $/ \mathrm{ml}$ \\
\hline $\begin{array}{l}\text { Pollicino et al., J.Virol } \\
\text { 2011; 85: 432-9 }\end{array}$ & $\begin{array}{l}\text { TRIzol reagent } \\
\text { (Invitrogen) }\end{array}$ & $\begin{array}{l}\text { Oligo(dt)primers } \\
\text { SuperScript Reverse } \\
\text { Transcriptase kit } \\
\text { (Invitrogen) }\end{array}$ & $\begin{array}{l}\text { Primer DELTAF: } \\
\text { nt 1063-1081 } \\
\text { Primer DELTAR: } \\
\text { Nt 1236-1216 } \\
\text { Probe DELTA/FL: } \\
\text { nt 1086-1108 } \\
\text { Probe DELTA/LC: } \\
\text { nt 1113-1137 } \\
\end{array}$ & 1 & $\begin{array}{l}\text { Cobas TaqMan } 48 \\
\text { (Roche Diagnostics) }\end{array}$ & Plasmid pCRII-delta-R0 & $\begin{array}{l}1 \times 10^{1} \ddot{i} 1 \times 10^{7} \\
\text { copies/ml }\end{array}$ & $1 \times 10^{1}$ copies $/ \mathrm{ml}$ \\
\hline
\end{tabular}

$n r:$ not reported 
Table III: principal technical features of commercial assay for HDV-RNA quantification

\begin{tabular}{|c|c|c|c|c|c|c|c|}
\hline ASSAYS & $\begin{array}{c}\text { HDV-RNA } \\
\text { EXTRACTION }\end{array}$ & $\begin{array}{c}\text { REVERSE } \\
\text { TRANSCRIPTION }\end{array}$ & $\begin{array}{l}\text { TARGET } \\
\text { REGION }\end{array}$ & $\begin{array}{l}\text { GENOTYPES } \\
\text { DETECTED }\end{array}$ & STANDARD & LINEARITY & $\begin{array}{c}\text { LIMIT OF } \\
\text { DETECTION }\end{array}$ \\
\hline $\begin{array}{c}\text { RoboGene } \\
\text { HDV RNA } \\
\text { Quantifcation } \\
\text { kit }\end{array}$ & $\begin{array}{c}\text { INSTANT Virus } \\
\text { RNA Kit, version } \\
\text { HDV (AJ } \\
\text { Innuscreen) or } \\
\text { QIAmp Viral RNA } \\
\text { Mini Kit (Qiagen) }\end{array}$ & One Step & $\begin{array}{l}\text { HDAg- } \\
\text { coding } \\
\text { region }\end{array}$ & $1-8$ & $\begin{array}{l}\text { Synthetic } \\
\text { HDV HDag } \\
\text { RNA }\end{array}$ & $\begin{array}{c}1 \times 10^{1} \ddot{i} 1 \times 10^{7} \\
\text { copies/run }\end{array}$ & $\begin{array}{c}1 \times 10^{1} \\
\text { copies/run }\end{array}$ \\
\hline $\begin{array}{c}\text { DIA.PRO } \\
\text { HDV RNA } \\
\text { Quantitation }\end{array}$ & $\begin{array}{l}\text { QIAmp Viral RNA } \\
\text { Mini Kit (Qiagen) }\end{array}$ & $\frac{\text { RNA }}{\text { retrotranscription Kit }}$ & $n r$ & $n r$ & $\begin{array}{c}\text { External } \\
\text { standard curve }\end{array}$ & $\begin{array}{l}10^{3} \ddot{\text { i }} 10^{12} \\
\text { copies/ml }\end{array}$ & 1 copies $/ \mu 1$ \\
\hline $\begin{array}{l}\text { PrimerDesign } \\
\text { Quantification } \\
\text { Kit for HDV } \\
\text { genomes }\end{array}$ & $n r$ & $\begin{array}{l}\text { PrimerDesign } \\
\text { Precision Reverse } \\
\text { Transcription kit }\end{array}$ & $\begin{array}{l}\text { HDAg- } \\
\text { coding } \\
\text { region }\end{array}$ & $1-7$ & $\begin{array}{c}\text { Positive } \\
\text { control } \\
\text { template to } \\
\text { generate a } \\
\text { standard curve }\end{array}$ & $\begin{array}{c}1 \times 10^{2} \ddot{i} 1 \times 10^{8} \\
\text { copies } / \mathrm{ml}\end{array}$ & $\begin{array}{c}1 \times 10^{2} \\
\text { copies/ml }\end{array}$ \\
\hline
\end{tabular}

$n r:$ not reported 


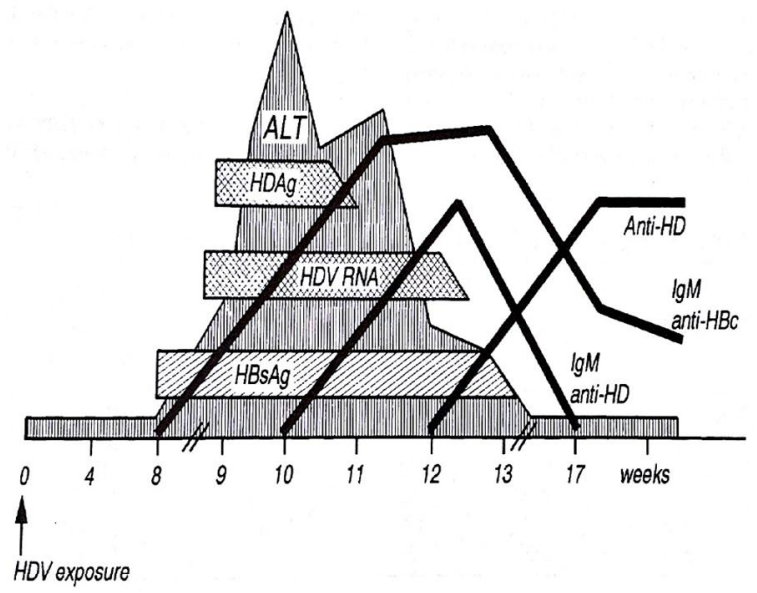

Fig. 1A 


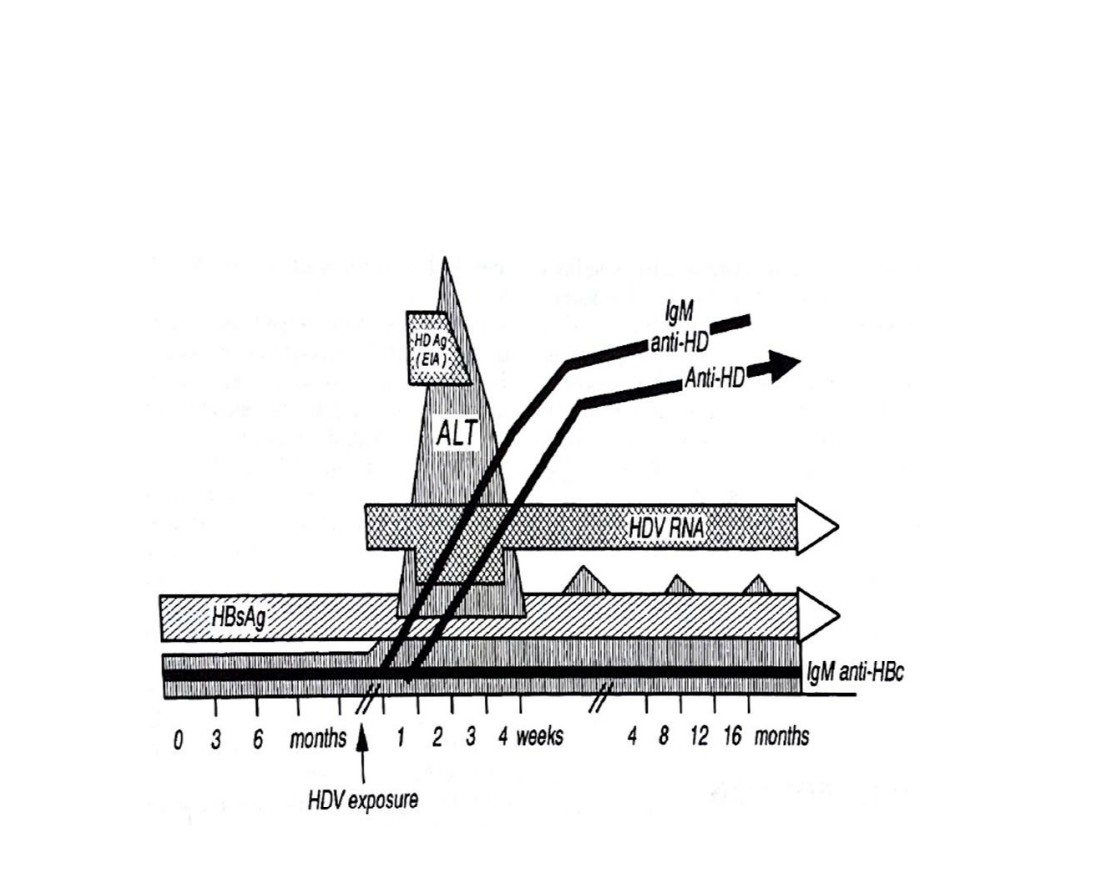


qHDV-RNA assays (dinamic range $10^{1}$ ï $10^{8}$ copies $/ \mathrm{ml}$ )

Year of introduction

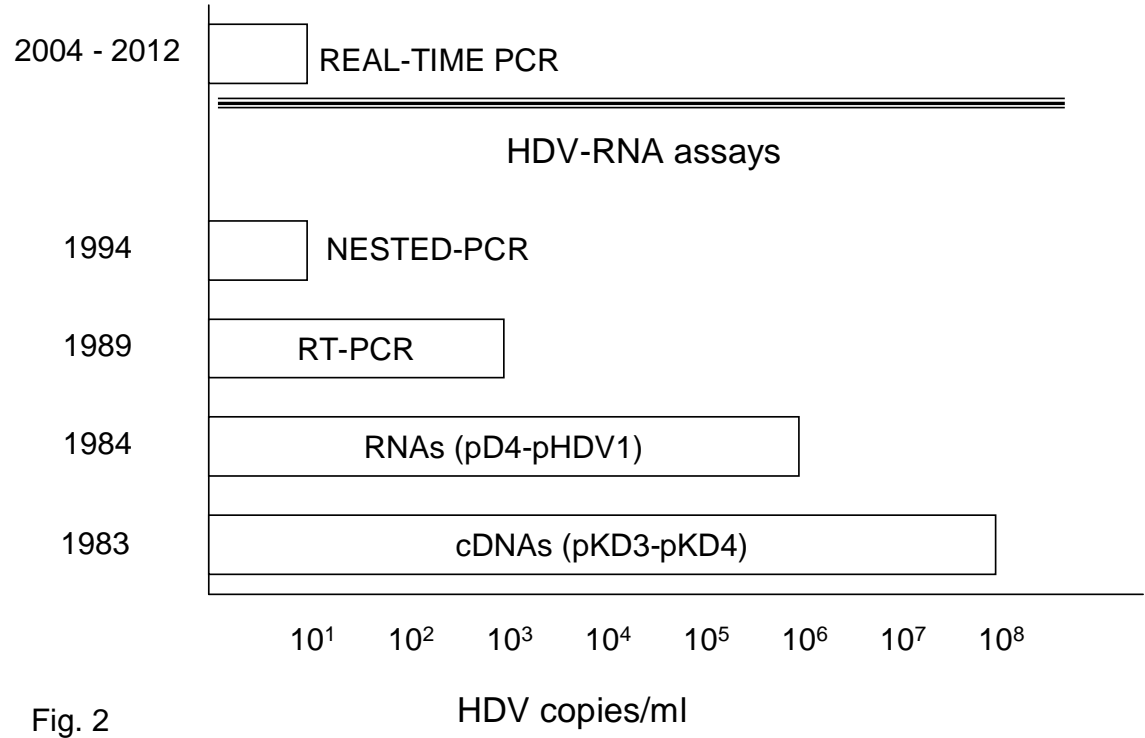

